\title{
The History from the View of the Founder Fathers of the Republic of Turkey: The War of Independence
}

\author{
Ahmet Vurgun ${ }^{1} \&$ Muhammet Avaroğulları ${ }^{2}$ \\ ${ }^{1}$ School of Education, Marmara University, Istanbul, Turkey \\ ${ }^{2}$ School of Education, Mugla Sitkı Koçman University, Muğla, Turkey \\ Correspondence: Muhammet Avaroğulları, School of Education, Mugla Sitkı Koçman University, 48000 \\ Menteşe, Muğla, Turkey. E-mail: Muhammet@mu.edu.tr
}

Received: March 18, 2021

Accepted: July 3, $2021 \quad$ Online Published: July 10, 2021

doi:10.5539/jel.v10n4p202

URL: https://doi.org/10.5539/jel.v10n4p202

\begin{abstract}
This study aims to reveal how the Turkish War of Independence was told in the history textbooks in elementary schools to the Republic of Turkey's first generation. The research has been carried out using the historical research method, one of the qualitative research methods. The data of the study have been collected through the primary school history textbooks published between 1924-1928. The data have been obtained through document review. According to the research findings, the subjects of Istanbul's occupation, the occupation of Izmir, the resistance against invasions, the Battles of Inonu, the Eastern Front, the Battle of Sakarya and the Battle of Dumlupınar are included in the textbooks. In contrast, the Battle of Kütahya-Eskişehir is not included. It is understood that since the textbooks were written right after the War of Independence, this directly affected the content and the language used. It is possible to see the enthusiasm, emotion, excitement, and perspective of the Turkish War of Independence in the textbooks. This situation shows that the process and the atmosphere in the country affect the history education. Moreover, it has been observed that the subjects were told in the form of stories, taking into account the students' cognitive levels. It is remarkable how the Republic's fathers told and conveyed the Turkish War of Independence to the Republic's children about the events that took place just recently. In conclusion, this study demonstrates how the present-day Turkish history textbooks have evolved from those entirely subjective textbooks of the early Republic era.
\end{abstract}

Keywords: Turkish war of independence, history education, elementary education, textbooks

\section{Introduction}

Having the Turkish War of Independence been completed with success and the Republic's proclamation, a new era has begun in Turkey. During this period, various steps were taken in education as in every field. In the first years of the Republic, Ataturk's speeches and views on education were taken as the road map of the "Turkish Education System" by the period's educators. These views, as well as drawing the framework of national education, have influenced the school history programs as the essential tool of citizenship transmission and political socialization (Ata, 2000). With the Unification of Education Law enacted on the 3rd of March 1924, all the educational institutions in the country were gathered under one roof. The curriculums and textbooks began to be rearranged in line with the Republic's principles (Aslan, 2012). In this direction, the first step was taken in the 2nd Scientific Commission, which convened on 23 April 1924, under the chairmanship of Vasıf Çınar, the minister of education, and the first and primary school curriculum of the Republic was prepared. The 1924 curriculum was designed by forty-three people working for 24 days. The educators such as Ali Haydar Taner, Nafi Atuf Kansu, Mustafa Şekip Tunç, İhsan Sungu, İsmail Hakkı Baltacıoğlu, Fuat Köprülü, and Kazım Nami Duru, who knew the history and education debates of the Constitutional Period, took part in the commission. This commission prepared the new curriculum according to the Republic's principles (Ata, 2014).

In the 1924 curriculum, which is the Republic's first curriculum, the history was included in the 3rd, 4th and 5th grades of primary school. The curriculum focused on especially nature and content of the history course in the $3^{\text {rd }}$ grade. The curriculum stated that the 3rd-grade history course would be taught in the forms of reading and conversation. Besides, the important events between 1908 and 1924 would be narrated to attract the attention of children. The period of national awakening, i.e., the period between the beginning of national movements in Anatolia and the Republic's declaration, would be emphasized. The great personalities of this time would be 
explained. Besides, in the 5th-grade program, the period of national awakening, i.e., the Turkish War of Independence, was among the topics to be covered (Maarif Vekâleti, 1924). In this first curriculum of the Republic of Turkey, the issues relating to the sultanate, Ottoman dynasty, and caliphate were removed and replaced with the Turkish war of independence and the Republic's proclamation. In this way, the path to the establishment of the Republic of Turkey started to take place in history curriculums and textbooks (Aslan, 2012). These changes indicate that the scope and purpose of history education in Turkey were shifted in parallel to alterations in the regime.

In the 1924 curriculum, a significant development took place in terms of pedagogy. The teaching approach that has preceded the teaching in recent times over the distant past was included in the history curriculum. According to Ata, "the aim of the educators who made the history programs were to teach the developments that led to the Turkish War of Independence and the proclamation of the Republic to a large audience that will start working immediately after primary school" (Ata, 2014), so this has been influential in the implementation of this history teaching approach.

The hasty preparation of the 1924 curriculum and its acceptance as a temporary curriculum led to a new curriculum design after a short while. Also, it was pointed out that the primary school's main purpose was to raise young generations as active and good citizens, and thus the changes were made in the current curriculum to achieve this goal properly (Maarif Vekâleti, 1926). As a result, a new curriculum was prepared in 1926 to eliminate the problems and deficiencies observed in practice. This new curriculum was piloted in a few schools in the 1926-1927 academic year and implemented in all schools in the country, beginning with the 1927-1928 academic year (Aslan, 2011; Çapa, 2012).

Looking at the history course's place in the 1926 curriculum, first of all, the objectives of the course draw attention:

1) To inform children about the past of the Turkish nation and to raise awareness in them.

2) To explain that today's civilization is the product of a long past

3) To Describe the life and movements of great individuals, thus providing examples that will serve as models for children (Maarif Vekâleti, 1926).

The new curriculum stated that Turkish history would form the center of education and that the essential parts of general history would be taught in the context of their relationship to Turkish history (Maarif Vekâleti, 1926). The history course was given two hours a week in the 4th and 5th primary school grades in the curriculum. As in the previous program, the new program's topics were brought until the Republic's declaration (Maarif Vekâleti, 1926). This shows that the Turkish War of Independence and the period leading to the Republic's proclamation were intended to be transmitted to primary school students. Ataturk, the National Struggle leader and the founder of the Republic, examined this curriculum in detail and highlighted especially the sections related to history course in the new curriculum. Ataturk specifically marked the 3rd item mentioned above among the aims of the course (Ata, 1998).

Although there is continuity from the 2nd constitutional period until the early 1930s in Turkey's history education, partial changes have been made since then. Ottoman history no longer constitutes the main point of national history; instead, the new state's history comes to the fore. In this process, by giving importance to the understanding of national history, Turkish history was handled in integrity from the beginning until the Republic's declaration, and history curricula and textbooks were prepared in line with the idea of national history (Çapa, 2012; Engin, 2015; Vurgun, 2016). The historical understanding of the period reflected its effect directly, even on the names of the textbooks. For example, the textbook "National History," published by Fuat Köprülü during the War of Independence, was republished under the same title in line with the 1924 and 1926 curriculums. Authors such as Ahmet Refik, İhsan Şerif, Emin Ali, Ali Reşat, who were among the educators and writers of the Constitutional Period, prepared history textbooks according to the new curriculum as well (Çapa, 2012; Keleş \& Kiriş, 2006). The influence of the nation-state ideal of the Republic can be seen in the names of these textbooks. For example, the book "Our History" refers to the common "we" aiming at building a nation; the book "History Lessons for the Children of the Republic" also shows the importance given to the new regime (Alaca, 2017). On the other hand, the new textbooks for secondary and high schools were prepared later, and the textbooks of the 2nd Constitutional Monarchy period continued to be used with minor changes (Çapa, 2012). Finally, with the historical studies that started under the leadership of Ataturk in the early 1930s, the new textbooks were prepared for all school levels, especially for high schools (Çapa, 2012). Thus, a new era in history education started after 1930, and the steps taken for new history education in the first years of the Republic were finalized with the Turkish History Thesis (Vurgun, 2016). 


\subsection{Purpose and Significance of the Research}

History teaching is shaped by the meaning attributed to the function of history. When it takes on the mission of preparing society for the future, history is a discipline that produces generalizations and theories that teach lessons (Dilek, 2007). Again, teaching the knowledge of the past with history courses aims to cultivate good citizens who know and adopt its history, society, values, and culture (Demircioğlu, 2007). At this point, the most important feature of history is that it is a tool employed to define identity. History education constitutes the primary reference for constructing a nation and national identity (Pamuk, 2014). Schools come to the fore to fulfill this function of history and history education in modern societies. Likewise, the task of raising citizens following the ideas and ideology of the rulers was given to schools within the education system and history courses within the school (Alabaş, 2019). Textbooks are one of the most important materials for a history course to fulfill this function in schools. History textbooks transfer knowledge and engrave political and social norms into pupils' memory in the education process. As a teaching material, history textbooks try to explain who we are. In this respect, beyond being pedagogical as educational material, it has a political function. Curriculums and textbooks prepared by governments affect students' personalities, beliefs, and perspectives on life (Pingel, 2004; Şimşek, 2019). Another feature of the textbooks is their ability to create an image in the readers' minds with the information they contain (Köksal, 2019). Studies to be made on textbooks, which are the products of their period, gain much meaning as they show the relationship between state-politics and education in the past (Ata, 2017).

This study aims to reveal how the Turkish War of Independence was described to children in the first years of the Republic of Turkey through elementary school history textbooks. The Turkish War of Independence or the National Struggle can be defined as the resistance, and the total fight started after the Armistice of Mudros (30 October, 1918) made against forces that invaded Turkey. The Turkish War of Independence, which has two pillars, military and political, ends with the (the 11th October, 1922) in military terms and the Lausanne Treaty (the 24th July, 1923) politically (Küçük, 2005). The subject of the Turkish War of Independence, i.e., the story of the Republic of Turkey's founding, has always taken place in the history textbooks at all levels in the Republican Era. In particular, this subject's importance is understood more in the curriculum and textbooks prepared immediately after the establishment of the Republic of Turkey. Considering that history teaching started at an early age in many places with a modern education system (Aktın \& Dilek, 2014, p. 38), the importance that the Republican administration will attach to the history lesson and especially to the teaching of the process leading to the Republic in history lessons will be seen clearly. Although the cognitive development of primary school students is limited, the creation of awareness about national history seems essential (Şimşek \& Çakmakçı, 2019). Educators of the early Republic believed that historical understanding in society is formed mainly in primary school. Thus, a significant part of the population learned these subjects in primary school during the Republic's early years. Considering the number of schools and their degrees in the first years of the Republic, it is more clearly understood how vital history education in primary school was for the new regime (Öztürk \& Yılmaz, 2001). In this context, an examination of textbooks and the history education in the first years of the Republic, which is one of the turning points of modern Turkey's history, will provide a specific contribution to historical and educational research. Likewise, it is understood that there are quite a limited number of studies on this subject (Aslan, 2010; Aslan, 2011; Aslan, 2012; Ata, 1998; Ata, 2000; Çapa, 2002, Çapa 2012; Gürkan, 2017; Öztürk \& Y1lmaz, 2001). Apart from this limited number of studies, the history education and historical understanding of the period has been studied mostly in the context of the post-1930 "Turkish History Thesis" era (Aslan, 2011). This situation reveals that the history education of the Atatürk period should be examined more thoroughly. In this study, both the understanding of history in the first years of the Republic of Turkey and the history education in the period will be determined by examining the textbooks. Besides, the new regime's effects, which was still in the institutionalization stage, on the history education will be discussed. The period we are in today corresponds to the 100th year of the National Struggle. This situation increases the importance of the study and provides an opportunity to look at the situation a century ago. In this context, how the Republic's fathers explained and conveyed the Turkish War of Independence to the children of the Republic and the learning process of the Republic's children about the events that took place recently is quite remarkable. With this aspect, this study describes how grandparents told their grandchildren the story of the establishment of the Republic of Turkey.

\section{Methods}

\subsection{Model of the Research}

In this research, the subject of the Turkish War of Independence in the primary school history textbooks in the first years of the Republic was examined. In this respect, the study is a descriptive study that explores the history education of the period by compiling and analyzing the findings on the subject (Aksoy, 2013). The most appropriate research method to achieve this goal is qualitative research. Qualitative research is "a form of research 
in which qualitative data collection methods such as observation, interview, and document analysis are used, and a qualitative process is followed to reveal perceptions and facts realistically and holistically in the natural environment" (Yıldırım \& Şimşek, 2018). Here, the historical research, one of the qualitative research methods, has been used in this study. Historical research is the systematic collection and evaluation of data to define, explain, and understand past actions and events (Fraenkel, Wallen, \& Hyun, 2011). In this study, as a requirement of historical research, the period's primary sources have been used. The situation in primary school history education has been tried to be described based on the period's documents. While doing this, it has been pushed to examine how the textbooks convey the events in a certain period of history to children and how the structure the events were presented in were formed.

\subsection{Data Collection and Analysis}

Primary school history textbooks in the first years of the Republic (1924-1928) constitute the research's primary data source. These data have been obtained through document analysis, one of the methods frequently used in historical research. Document analysis is the analysis of written materials that provide information about the facts and events aimed to be investigated (Yıldırım \& Şimşek, 2018). The textbooks, which are the study's primary data source, were obtained from the Istanbul Metropolitan Municipality Ataturk Library and Ataturk University Seyfettin Özege collection. In line with the purpose of the study, eight different textbooks that were taught in primary schools at that time have been analyzed. Then, the parts of the textbooks related to the research subject have been transcribed into the present-day Turkish alphabet from the Ottoman alphabet used in the textbooks. The data obtained through the document analysis have been compiled within the framework of specific concepts and themes and interpreted so that the reader can understand. In this context, the data obtained from the relevant textbooks have been sorted and categorized chronologically and analyzed. The textbooks examined within the scope of the research are presented in the table below:

Table 1. Primary school history textbooks between 1924-1928

\begin{tabular}{llll}
\hline Textbook & Author & Year & Grade \\
\hline Our History & Ahmet Halit & 1924 & 3 \\
National History & Fuat Köprülü & 1924 & 5 \\
History of Turkey & Ahmet Refik & 1925 & 3 \\
History Lessons for the Children of the Republic & İhsan Şerif & 1926 & 5 \\
History Lessons for Turkish Children & Emin Ali & 1927 & 5 \\
History in the Republic & İhsan Şerif & $1927-1928$ & 4 \\
History Lessons for Primary Schools & Ali Reşat & 1928 & 4 \\
History Information for Children & Ahmet Refik & 1928 & 5 \\
\hline
\end{tabular}

\section{Findings}

The findings of the research are the subjects within the scope of the Turkish War of Independence. Topics chronologically begin with the invasion of Turkey's land by the Allies and continue with its impact and end with a discussion of backlash against this occupation. Subsequently, the military struggle carried out by the Turkish nation against the invaders and especially the Greeks; presented with the İnönü, Sakarya and Dumlupınar Wars, ended with the liberation of İzmir on the 9th of September, 1922.

\subsection{Occupations}

Immediately after the Armistice of Mudros, the Allies began to invade Turkey's territory (Ataturk, 2005). In the history textbooks we have examined, occupations are also mentioned, and Istanbul and Izmir's occupation is emphasized.

\subsubsection{Occupation of Istanbul}

Istanbul, the Ottoman Empire's capital, was first de facto occupied by the Entente States immediately after the Armistice of Mudros; occupation de jure came after 1.5 years (Köstüklü, 2013). Both occupation processes of Istanbul and the hostile acts committed by the occupiers are explained in the textbooks as follows:

"After our enemies invaded Istanbul, they did not leave any disgrace and treason that is not committed. Sometimes enemy policemen and soldiers would go into cafes and houses and steal people's money on the pretext of looking for weapons." (Ahmet Halit, 1924, p. 8).

“Allies' navies entered Istanbul. They placed their soldiers at various points. They took weapons from our 
hands even they called our pocket knives as weapons and took and threw them from our houses. They stole our belongings. They extorted the shopkeepers. So-called civilization bearers! They made all the banditry in the world completely." (İhsan Şerif, 1927-1928, pp. 115-116).

"The British dissolved the parliament in Istanbul to prevent these movements that took place in Anatolia. They arrested many of the deputies. They declared that the city was under their occupation de jure on the 16th of March 1920." (Emin Ali, 1927, p. 142).

\subsubsection{Occupation of Izmir}

After the occupation of Istanbul, the most focused issue is the occupation of Izmir. Izmir's invasion by Greece with the approval of the British and evil perpetrated by the Greek soldiers after the invasion are clearly described in the books:

"Statesmen were in favor of the British. The British paid no attention to this support. They let the Greek soldier enter Izmir. The miserable soldiers of Greece, painting the roads they passed in Turkish blood, entered Izmir, killed our officers. Native Greeks and Armenians were together with the Greeks, and they tried to clear Turks from beautiful Izmir." (Ahmet Refik, 1925, p. 16).

"Mean Greek did not leave any wildness that is not committed in Izmir. Thousands of Turks were martyred every day; every day, the villainous enemy was moving forward. The dishonorable and unscrupulous enemy who enjoys drinking the blood of every individual, up to the children in the swaddle, proved every minute what a mean creature he was." (Ahmet Halit, 1924, p. 9).

\subsection{The Impact of the Occupations and the Resistance}

While focusing on the occupation of Istanbul and Izmir and the hostile acts committed by the occupation forces in this process, the effect of these events on Turkish society, the psychology of the people, and how it fueled the War of Independence is also emphasized in the textbooks:

"Izmir was occupied by the Greeks. Listen, Turkish boy; from that moment on, the past for us had been completed and knotted. A new history has begun then. Tens of thousands of people gathered in Istanbul every day, "Izmir is ours!" they were screaming, going crazy with their grief." (Ahmet Halit, 1924, p. 9).

"The Izmir disaster struck Turks' hearts. The persecution of the British and the French made the Turks risk everything. Love for independence suddenly sparked. But there was neither cannon nor rifle in their hands. The army was scattered. Even so, the Turks risked everything. They prepared to make a War of Independence against all of Europe." (Ahmet Refik, 1928, p. 156).

"It was impossible to bear these insults for a great and glorious nation that has been accustomed to living independently for thousands of years. The flames of revenge began to burn in the hearts of every Turk. The nation was tired of fifteen years of war and yet, did not lose hope despite being unarmed." (Fuat Köprülü, 1924, pp. 103-104).

In the textbooks examined, it is seen that detailed information is given about how the military phase of the National Struggle against invasions began and how the process led to the War of Independence. In this context, first of all, the beginning date of the military phase was clearly stated. Then, the critical concepts of the military process were analyzed, and the meanings of the War of Independence and the Kuva-y1 Milliye, that is, the National Forces, i.e., local militia, were explained:

"War of independence started in the form of gang wars with the people embracing arms on the sides of Izmir and Aydin when the Greeks stepped foot in Izmir." (Emin Ali, 1927, p. 141).

"Altruistic people who came forward for the war of independence in Anatolia were called national forces." (Ahmet Halit, 1924, p. 12).

"The wars that started with the arrival of the Greeks in Izmir are called the national wars of independence. This war was a war of independence against the enemies who wanted to destroy the Turkish nation's independence and take away their homeland." (Emin Ali, 1927, p. 140).

It is underlined that In the beginning, the resistance was not only against the invaders but also a military struggle was undertaken with the Istanbul government. For example, it was stated that Sultan Vahdettin ordered a fatwa about the National Forces, which declares them as "traitors," and tried to start a revolt in Anatolia with a force called the caliphate army, but failed (İhsan Şerif, 1926, p. 112). It is also emphasized that the Istanbul government cooperated with the British and Greeks and took action against the national forces, but they were defeated:

"Vahdettin and the traitors of Freedom and Entente, whom he brought to power, were collaborating with the 
Greeks on the orders of the British. On the one hand, they sent a miserable force they gathered under the caliphate army's name to fight Mustafa Kemal Pasha; on the other hand, they were trying to start an uprising in Anatolia. But the national forces dispersed these traitors in a short time" (Fuat Köprülü, 1924, pp. 105-106).

\subsection{Battles of Inonu}

The developments that took place during the War of Independence required the establishment of a regular army. After a while, the national forces were dissolved, and the regular Turkish army was formed. The regular army won its first victory against the Greeks on the western front in Inonu (Köstüklü, 2013, p. 27). Battles of Inonu, where the regular Turkish army won a victory over the Greeks, constitute the post local militia phase of the Turkish War of Independence. In the textbooks examined, Battles of Inonu are told like a victorious story of the national army, which demonstrates that the authors take the pupils' age into consideration:

"The British had sent the most awesome weapons and cannons to the Greek army. The Anatolian soldier was the national army. This army was the young Turkish army with a national vision. The Greek army was spoiled. Its gun, rifle, tanks, cars, and aircraft were all in place. On the other hand, the Anatolian army had nothing. The Greeks were sure of victory and advanced into Anatolia. The two armies met in Inonu. The Greeks fought with the ambition of invasion and rape, and the Turks with the fire of patriotism and independence. The battle lasted for hours. The courage of the Turks was wonderful. Even women participated in the war. The young Turkish soldier stood against the enemy with his iron chest. He did not take the beautiful Anatolia away from his eyes. The battle lasted for days. The morning of 11 January was enlightened with the victory of the Turks. Young Turkish army knocked out an enemy three times superior to it in Inonu." (Ahmet Refik, 1925, pp. 21-22).

What the Greeks did with the effect of their defeat in Battles of İnönü was also mentioned:

"Our national army crushed the Greek army twice in Inonu. Greeks brutally massacred Turkish villages on the edge of the Marmara to take the revenge of this defeat." (Fuat Köprülü, 1924, p. 107).

In addition to these, it is seen in the textbooks that Battles of Inonu were the first victory of the regular army and the government of the Turkish Grand National Assembly, and the heroism of İsmet (Inonu) Pasha was emphasized:

"Inonu became a place of honor for Turkish heroes. The Battles of İnönü resulted in the disastrous defeat of Greece. This was the first victory of the TGNA government." (Ahmet Halit, 1924, p. 14).

"Ismet Pasha won this victory. He became famous as the hero of İnönü. This was the first national victory of the Turks." (Ahmet Refik, 1928, p. 160).

\subsection{Eastern Front}

Another front of the Turkish War of Independence was fought in the east and against the Armenians. The Armenian forces were defeated quickly, Kars was liberated from the occupation, and Gyumri was entered. The Treaty of Gyumri was signed on the 3rd of December, 1920 by accepting Armenians' peace requests. This agreement went down in history as a diplomatic result of the first military success of the Turkish Grand National Assembly (Beyoğlu, 2012, p. 133). In the primary school history textbooks examined within the research scope, the eastern front developments were also mentioned. It was pointed out that this struggle on the eastern front is essential for the safety and success of the Western Front. The textbooks tried to present the events according to pupils' cognitive level:

“To be free in the West, it was necessary to crush Armenia first.” (Fuat Köprülü, 1924).

"The Armenians even tried to surround our army from behind and knock it down. Our heroic army destroyed the entire Armenian force in two to three weeks." (İhsan Şerif, 1927-1928, pp. 120-121).

"Kazim Karabekir Pasha did not allow Armenia to strengthen. He marched to Armenia; Sarıkamıs, Kars, Gyumri fell into Turkish hands. He gave the weapons and ammunition he captured from the Armenians to the heroes of the western front of Anatolia. Thus, the Armenians' whim to found a kingdom was destroyed." (Ahmet Refik, 1925, pp. 20-21).

It is noteworthy that in the textbooks examined, front commander Kazım Karabekir Pasha's name was mentioned in the textbooks published in 1924 and 1925. However, in the books published after 1926, his name was not mentioned. Instead the army, in general, was referred to as the victorious. For example, in the book called "History of Turkey," which was printed in 1925, it is written that "Karabekir Kazim Pasha, did not let the Armenian forces get stronger ...". Likewise, in the 1924 textbook "Our History," it is said that" it was necessary to put Armenians bring into line. Kazım Karabekir Pasha, one of our commanders, taught them a good lesson ..." (Ahmet Refik, 
1925, p. 20; Ahmet Halit, 1924, p. 15). However, in the textbooks published in 1927 and afterward, Kazım Karabekir Pasha was not mentioned. Based on this, it can be said that the political developments of the period were influential on the textbooks.

\subsection{Battle of Sakarya}

The turning point of the Turkish War of Independence was the Battle of Sakarya. This war, which Mustafa Kemal Pasha described as the great bloodshed, lasted 22 days and 22 nights, and the Turkish army won a great victory (Arl, 2013). The importance and feature of the Battle of Sakarya have been emphasized in the examined primary school history textbooks. In this context, it is seen that attention is drawn to the pre-war situation and the cause of the war: "Our armies retreated to Sakarya River after the Inönü victories. The Greeks found an opportunity to advance in the absence of our army. They said that Ankara was their target. Both to avenge two painful defeats and to hit us in the heart; they wanted to capture the center of government" (İhsan Şerif, 1927-1928, pp. 121-122). Likewise, the Greek army's aim was pointed out in another book: "The Greeks aimed to take Ankara" (Ahmet Refik, 1928, p. 160). In the textbooks, besides the Greeks' aim, the Turkish army's goal is also stated: "Our army, which had defeated the Greeks twice in Inonu before, was quietly preparing to deliver a decisive blow to the Greeks. The Greeks, on the other hand, were daydreaming of entering Ankara" (Ali Reşad, 1928, pp. 131-133).

It is also noticed that the names leading both armies are emphasized in the textbooks. It was stressed that Mustafa Kemal Pasha was leading the Turkish military and that he was declared as commander in chief by the parliament: "The Grand National Assembly gave Mustafa Kemal the post of commander in chief with all powers" (Emin Ali, 1927, p. 145), "Their king headed the Greek army and Mustafa Kemal Pasha became the head of the Turkish army" (Ahmet Refik, 1928, p. 160).

As in other military struggles, the Battle of Sakarya has been depicted in textbooks like a story, taking into account the levels of children:

"As the Greeks progressed, they were saying that they were one step closer to Ankara; they were happy and singing songs. They did not know that their every step forward brought them closer to their graves, not to Ankara a minute earlier. While they were chasing such sweet dreams, suddenly, a hell of doom broke out. It was not understood what happened. No one knew whether they fell out of the sky or rose from the ground. All the plains were filled with Turkish soldiers with iron claws...." (İhsan Şerif, 1927-1928, pp. 121-122).

\subsection{Battle of Dumlupinar}

The last and most important development of the Turkish War of Independence is the Great Offensive and the Battle of Dumlupınar. The Great Offensive, aiming to save Anatolia from the Greek occupation, started on the 26th of August, 1922. Under Mustafa Kemal Pasha's command, the Turkish army defeated the Greek army in the Battle of Dumlupinar on the 30th of August, 1922. Then, following the Greek military rapidly, the Turkish army entered İzmir in a short time, on the 9th of September, 1922. Thus, Anatolia, where no single Greek soldier left, was saved from the occupation (Köstüklü, 2013). When we categorize the information in the primary school history textbooks examined, it is seen that, first of all, the distinctive feature of war is brought to attention. The Battle of Dumlupinar, unlike other actions and military developments, was a fight that the Turkish army was not defending but attacking. In other words, it was emphasized that this is an offensive battle on behalf of the Turks:

"Until now, the Turks were in a position of defense. This time they attacked." (İhsan Şerif, 1927-1928, p. 123).

"After The Battle of Sakarya, it was our turn to attack. The national armies carried out a general attack on the enemy trenches in Afyonkarahisar on the morning of the 26th of August, 1922." (Emin Ali, 1927, p. 147).

The aim of war is emphasized along with its characteristics in terms of military strategy. The goal is to clear Anatolian lands from the Greek army and liberate them from occupation. At this point, the explanation of the Commander-in-Chief Mustafa Kemal Pasha on the subject is included in the books:

"The Sakarya Victory frightened the British. They wanted to keep the Turks busy with negotiations again, but the Turks did not pay any attention. They prepared their armies. Gazi Mustafa Kemal spoke to the army as follows: "We will remove the enemy from the bosom of Anatolia. We will pour it into the sea from the place they set foot on our land! he said." (Ahmet Refik, 1928, p. 162).

"As our great savior said, it was necessary to make Anatolia a grave for the Greeks." (Ali Reşad, 1928, p. $133)$.

It is also pointed out in the textbooks that the Turkish army moved very quickly and destroyed the Greek army during the period after the Great Offensive (the 26th of August, 1922): 
"The armies led by our commander in chief left Afyonkarahisar, and within 15 days, they turned Anatolia into a grave for a hundred thousand people Greek army. They chase away the rest. The herd like murderers were poured into the sea from the Izmir dock, where they entered." (İhsan Şerif, 1927-1928, p. 123).

"Our heroic army, led by Ghazi Pasha himself, attacked the enemy with lightning speed and took Bursa and Izmir back in 10-15 days. The Greek army was destroyed completely." (Fuat Köprülü, 1924, p. 107).

It was stated in the textbooks that the occupations and especially the occupation of Izmir were a critical event that triggered the Turkish War of Independence. It was pointed out that the Turkish War of Independence came to an end with the liberation of Izmir after the Battle of Dumlupınar. Also, the defeat of the Greeks in the war narrative was expressed as "pouring into the sea":

"Ghazi Mustafa Kemal Pasha implemented the war plan with a success that astonished the whole world. After the armies led by our commander-in-chief defeated the Greeks in Afyonkarahisar, all the enemy was poured into the sea in a few days." (Ali Reşad, 1928, p. 133).

"No power could stop the Turkish army. The Turks completely destroyed the Greek military; those who escaped were driven to Izmir. They did not leave a single enemy in Anatolia, and they poured the Greeks into the sea of islands from where they entered, even captured their commander in chief (the 9th of September, 1922) (Ahmet Refik, 1925, p. 26).

It has been stated that the Battle of Dumlupinar has a special place in Turkish history as well as it is a symbol of heroism:

"The foundation of the Republic of Turkey was laid in Dumlupinar. Dumlupınar ensured the life and independence of the Turks (the 30th of August, 1338/1922). The Turks did not forget Dumlupinar, who gave them freedom and sovereignty. On the anniversary of this victory, they gathered in Dumlupinar with their victorious commanders at their heads. They erected a martyr soldier monument in Kayatepe to commemorate the martyrs who shed their blood in the Turkish homeland's struggle for freedom. They made Dumlupinar the kiblah of the Turkish victory and independence." (Ahmet Refik, 1925, p. 26).

\section{Conclusion and Discussion}

Besides being an educational material, the textbooks on history education in Turkey have assumed the role of a tool for students' mental configuration. It is especially possible to see this role in the textbooks prepared in line with the two curricula after the Republic's proclamation. The primary educational institutions in the first years of the Republic of Turkey were primary schools, and the vast majority of the population was trained there. For this reason, primary schools and primary school history education have been given importance in line with the goals and expectations of the new regime. When it comes to the Turkish War of Independence, which is the story of the new regime's foundation, this becomes even more important. In this study, how the Turkish War of Independence was presented to the children of the Republic through primary school history textbooks was discussed. The publication dates of the books examined within the research scope constitute the period of 1924-1928. These dates are very close to the Turkish War of Independence (1919-1922). For this reason, it is understood that the proximity of publication dates of the textbooks to the events they discuss directly affects the content and the language. In this context, when we evaluate the textbooks in terms of language, narrative, and discourse, the following conclusions have been reached: When we look at the textbooks examined, the first thing that draws attention is their subjective structure. Perhaps with the effect of just getting out of the War of Independence, the authors of the textbooks have never attempted to convey the events in objective terms. Besides, the textbooks try to make students see themselves as a side of this war by using expressions such as "we," "us," and "our" frequently: "After our enemies occupied Istanbul ..." (Ahmet Halit, 1924, p. 8). "After the Battle of Sakarya, it was our turn to attack" (Emin Ali, 1927, p. 147). "As our great savior said, it was necessary to make Anatolia a grave for the Greeks" (Ali Reşad, 1928, p. 133). "The armies led by our commander-in-chief ..." (İhsan Şerif, 1927-1928, p. 123).

Another point that draws attention in the textbooks is that "we" is identified with the righteous, hardworking, just, and fair, while "they" is consubstantiated with the incompetent unjust, and unfair. To illustrate, "Our enemies did not leave any disgrace and treason that is not committed ... They even stole the money of the people" (Ahmet Halit, 1924, p. 8). "They extorted the shopkeepers. They've done all the banditry in the world perfectly" (İhsan Şerif, 1927-1928, pp. 115-116). "Wretched soldiers of Greece entered Izmir, painting the roads they passed in Turkish blood" (Ahmet Refik, 1925, p. 16). They did not leave any kind of brutality that they did not commit. Thousands of (civilian) Turks were martyred every day. The enemy who enjoyed drinking the blood of every individual, including babies in swaddles, was proving every minute how dishonorable and evil he was" (Ahmet Halit, 1924, p. 
9). But this enemy was as incompetent as it was unjust: "The British had sent the most awesome weapons and cannons to the Greek army. The Greek army was spoiled. Its gun, rifle, tanks, cars, and aircraft were all in place. On the other hand, the Anatolian army had nothing. The Greeks were sure of victory and advanced into Anatolia. The two armies met in Inonu. The battle lasted for days. The morning of 11 January was enlightened with the victory of the Turks. Young Turkish army knocked out an enemy three times superior to it in Inonu" (Ahmet Refik, 1925, pp. 21-22).

Again, "we" is depicted as people who are persecuted by the enemy and heroically and selflessly resisting these injustices. "The Izmir disaster had penetrated their hearts, and the persecution of the British and the French made the Turks risk everything. Love for independence suddenly sparked. But there was neither cannon nor rifle in their hands. The army was scattered. Even so, the Turks risked everything. They prepared to make a War of Independence against all of Europe" (Ahmet Refik, 1928, p. 156). They wanted to fight because "it was impossible to bear these insults for a great and glorious nation that had been accustomed to living independently for thousands of years. The flames of revenge began to burn in the hearts of every Turk. The nation was tired of fifteen years of war and did not lose hope, although they were without weapons" (Fuat Köprülü, 1924, pp. 103, 104). "To the self-sacrificing persons who came forward for the War of Independence in Anatolia..." (Ahmet Halit, 1924, p. 12). "The courage of the Turks was wonderful. Even women participated in the war. Young Turkish soldier stood against the enemy with his iron chest..." (Ahmet Refik, 1925, pp. 21-22).

It is also noteworthy that in the textbooks, "we" is presented winner always. The battles lost by the Turks during the War of Independence are not included. In other words, an image of invincibility was drawn for Turks during the narration of the War of Independence. However, the Greeks had attacked after the Battles of Inonu and defeated the Turkish army in the Battle of Kütahya-Eskişehir, and the Turkish army retreated to the east of the Sakarya River (Beyoğlu, 2012). This situation is explained in a textbook with the expression, "Our armies retreated to Sakarya after the Inönü victories. The Greeks found an opportunity to advance in the absence of our army. They said that Ankara was their target. Both to avenge two painful defeats and to hit us in the heart; they wanted to capture the center of government" (Ihsan Şerif, 1927-1928, pp. 121-122). This depiction is insufficient to cover what happened in reality. Perhaps the textbook writers wanted to instill self-confidence in the children of the Republic. If one recalls the Ottoman Empire's position vis-à-vis Europeans in the last centuries, it can be understood why such self-confidence was necessary and vital.

There is also a lyrical style reminiscent of medieval heroic stories in textbooks. For example, "Their king headed the Greek army, and Mustafa Kemal Pasha became the head of the Turkish army" (Ahmet Refik, 1928, p. 160). This sentence suggests that the war is between two knights rather than two nations. "Suddenly, a hell of doom broke out. It was not understood what happened. No one knew whether they fell out of the sky or rose from the ground. All the plains were filled with Turkish soldiers with iron claws...” (İhsan Şerif, 1927-1928, pp. 121-122). These supernatural associations bring to mind the epic stories of the medieval period. "Kazim Karabekir Pasha did not allow Armenia to strengthen. He marched to Armenia; Sarlkamış, Kars, Gyumri fell into Turkish hands. He gave the weapons and ammunition he captured from the Armenians to the heroes of the western front of Anatolia. Thus, the Armenians' whim to found a kingdom was destroyed (Ahmet Refik, 1925, pp. 20-21). Again, an epic understanding stands out here, as a bold person easily wins success. The reason for including these expressions may be that they think they are more suitable for the student's cognitive level. On the other hand, it can be believed that the fact that the Turks have won a clear victory for the first time in a long time has also excited the textbook writers, and they use such expressions because the events are still scorching. All these show that the enthusiasm, emotion, excitement, and perspective created by the Turkish War of Independence were transferred to the textbooks. In other words, the process experienced directly affected the history education.

When discussing the course books of the period, it is necessary to consider the age range of the children who read them. Likewise, children who read primary school history textbooks between 1924 and 1928 were the first generation of the Republic and were personally affected by the Turkish War of Independence. In other words, a history that is experienced, heard, and felt transformed into a history and history education that is written and read. In conclusion, this study, which examines the turning point of the Turkish history, gives an idea about the development of the history education in Turkey. Also, it sheds light on history education and children's education in post World War I Era in the world by focusing on the case of Turkish history education and becomes an example for the studies that will be conducted in other countries.

Finally, the examining of the textbooks of the early republican period reveals that these books are extremely problematic in terms of objectivity. According to Bodou, historical objectivity is based on three pillars. These are: evidence, selection and interpretation/explanation. The textbooks have problems in terms of all three criteria. First of all, very little evidence is given in the textbooks. Students are expected to believe in authority. There are 
similar problems with selection. As mentioned above, the issues that might be against the Turks were carefully avoided. There is no satisfactory discourse on the thoughts of the Greeks about war or the factors that pushed them to fight. Of course, historians have certain ideas about what is important, and as a result they make selections in content (Carr, 1996). However, we think that in a book written for students, the responsibility of the historian should be to try to be as objective as possible. There is no indication that textbook authors have made an effort in this direction. The textbooks are also extremely authoritarian in terms of the interpretation of the events. They do not offer the student the opportunity to make any alternative interpretations, they dictate their own understanding. The objectivity problem in this study has emerged as an example that today's textbook authors should carefully avoid.

\section{References}

Ahmet, H. (1924). Bizim tarih. İstanbul: Amedi Matbaas1.

Ahmet, R. (1925). Türkiye tarihi. İstanbul: İbrahim Hilmi.

Ahmet, R. (1928). Çocuklara tarih bilgisi. İstanbul: İbrahim Hilmi.

Aksoy, M. (2013). Bilimin mabedinde yöntem meselesi. İstanbul: Yeni İnsan.

Aktın, K., \& Dilek, G. (2014). Tarih/sosyal bilgiler öğretim programlarında okul öncesi dönemde tarih öğretimi: ABD örneği. Uluslararası Avrasya sosyal Bilimler Dergisi, 5(16), 36-56.

Alabaş, R. (2019). Cumhuriyet ve çocuk. İstanbul: Yeni İnsan.

Alaca, E. (2017). Tarih eğitimine giriş. Ankara: Pegem.

Ali, R. (1928). Illk mekteplere tarih dersleri. İstanbul: Türk Neşriyat Yurdu.

Arı, K. (2013). Başlangıçtan günümüze türk devrim tarihi. İzmir: Zeus.

Aslan, E. (2010). Türkiye cumhuriyeti’nin ilk ders kitapları. Eğitim ve Bilim, 35(158), 215-231.

Aslan, E. (2011). Osmanlı'nın “mekatib-i iptidaiye" sinden Türkiye Cumhuriyeti’nin "ilk mektepler" ine geçişte tarih programlarında değişim. Ankara Üniversitesi Türk Inkılap Tarihi Enstitüsü Atatürk Yolu Dergisi, 48, 749-777. https://doi.org/10.1501/Tite_0000000344

Aslan, E. (2012). Atatürk döneminde tarih eğitimi I: türk tarih tezi öncesi dönem (1923-1931). Eğitim ve Bilim, 37(164), 331-346.

Ata, B. (1998). John dewey ve türkiye'de ilköğretimde tarih öğretimi (1923-1930). In Ç. Baytekin \& B. Türkoğan (Yay. Haz.), Kocaeli Üniversitesi ve Atatürk Araştırma Merkezinin Ortaklaşa Düzenledikleri “Atatürk'ün Cumhuriyet'in İlanından Sonraki Hedefleri Sempozyumu” Bildirileri (pp. 57-77).

Ata, B. (2000). Atatürk, tarih öğretimi ve müzeler. Türk Yurdu, 20(160), 85-90.

Ata, B. (2014). 1924'te İlkokullarda tarih öğretimi: d'alembert etkisi altında türk deneyimi. Turkish History Education Journal, 3(1), 43-61. https://oi.org/10.17497/tuhed.40963

Ata, B. (2017). Tarih öğretiminin tarihi (1869-1922 dönemi). In İ. H. Demircioğlu \& E. Demircioğlu (Eds.), Türkiye'de Tarih Eğitimi Araştırmalarl El Kitabl (pp. 1-28). Ankara: Pegem. https://doi.org/10.14527/9786053188322.01

Atatürk, M. K. (2005). Nutuk (Haz. Z. Korkmaz). Ankara: Atatürk Araştırma Merkezi.

Beyoğlu, S. (2012). Tam bağımsızlığa giden yol: türk kurtuluş savaşı. In C. Öztürk (Ed.), Imparatorluktan Ulus Devlete Türk Inkllap Tarihi (pp. 125-162). Ankara: Pegem. https://doi.org/10.14527/9786053185949.04

Boadu, G. (2020), 'Hard' facts or 'soft' opinion? History teachers' reasoning about historical objectivity. Journal of International Social Studies, 10(1), 161-186.

Çapa, M. (2002). Cumhuriyet'in ilk yıllarında tarih öğretimi. Ankara Üniversitesi Türk İnklâp Tarihi Enstitüsü Atatürk Yolu Dergisi, 29-30, 39-55. https://doi.org/10.1501/Tite_0000000266

Çapa, M. (2012). Osmanlı imparatorluğundan türkiye cumhuriyetine geçiş sürecinde türkiye'de tarih öğretiminin tarihçesi. Trakya Üniversitesi Edebiyat Fakültesi Dergisi, 2(3), 1-28.

Carr, E. (1996). Tarih Nedir? İstanbul: İletişim Yayınları

Demircioğlu, İ. H. (2007). Tarih eğitiminde öğrenci merkezli yaklaşımlar. Ankara: Anı.

Dilek, D. (2007). Tarih derslerinde ögrrenme ve düşünce gelişimi. Ankara: Pegem.

Emin, A. (1927). Türk çocuklarına tarih dersleri. İstanbul: Suhulet Kütüphanesi. 
Engin, V. (2015). Osmanlı'dan cumhuriyet'e tarihi devamlllı. İstanbul: Yeditepe.

Fraenkel, J., Wallen, N., \& Hyun, H. (2011). How to design and evaluate research ineducation. New York: Connect Learn Succeed.

Fuat, K. (1924). Milli tarih. İstanbul: Kanaat Kütüphanesi ve Matbaası.

Gürkan, H. (2017). Türkiye'de tarih öğretimi ilköğretim ders kitapları (1869-1950). Adana: Karahan.

İhsan, Ş. (1926). Cumhuriyet çocuklarına tarih dersleri. İstanbul: Kanaat Kütüphanesi.

İhsan, Ş. (1927-1928). Cumhuriyette tarih. İstanbul: Kanaat Kütüphanesi.

Keleş, H., \& Kiriş, A. (2006). Bir osmanlı tarihçisi olan ali reşat'ın hayatı, eğitimciliği ve tarih öğretimi ile ilgili görüşleri. Kastamonu Eğitim Dergisi, 14(2), 571-586.

Köksal, H. (2019). Sunuş. In A. Şimşek (Ed.), Tarih Ders Kitaplarında Imajlar. Ankara: Pegem

Köstüklü, N. (2013). Atatürk ve türkiye cumhuriyeti tarihi araştırmaları I. Konya: Çizgi.

Küçük, C. (2005). Milli mücadele. Türkiye Diyanet Vakfi İslam Ansiklopedisi, 30, 76-83.

Maarif, V. (1924). Ilk Mektepler Müfredat Programı. İstanbul: Matbaayı Amire.

Maarif, V. (1926). Ilk Mektepler Müfredat Programı. İstanbul: Matbaayı Amire.

Öztürk, C., \& Yılmaz, A. (2001). Türkiye'de harf inkılabından önce kullanılan ilkokul tarih programları ve ders kitapları. KUYEB, 1(2), 409-427.

Pamuk, A. (2014). Kimlik ve tarih. İstanbul: Yeni İnsan.

Pingel, F. (2004). Ders kitaplarını araştırma ve düzeltme rehberi unesco (Çev. N. Elhüseyni). İstanbul: Türkiye Ekonomik ve Toplumsal Tarih Vakfi.

Şimşek, A. (2019). Giriş. In A. Şimşek (Ed.), Tarih Ders Kitaplarında İmajlar. Ankara: Pegem.

Şimşek, A., \& Çakmakçı, E. (2019). Cumhuriyet dönemi ilkokul tarih ders kitaplarında milli mücadele. Cumhuriyet tarihi Araştırmaları Dergisi, 15(30), 189-227.

Vurgun, A. (2016). Milli tarih nedir? İstanbul: Yeni İnsan.

Yıldırım, A., \& Şimşek, H. (2018). Sosyal bilimlerde nitel araştırma yöntemleri. Ankara: Seçkin.

\section{Copyrights}

Copyright for this article is retained by the author, with first publication rights granted to the journal.

This is an open-access article distributed under the terms and conditions of the Creative Commons Attribution license (http://creativecommons.org/licenses/by/4.0/). 